Document downloaded from:

http://hdl.handle.net/10251/84906

This paper must be cited as:

Gasque, M.; Martí, P.; Granero, B.; González Altozano, P. (2016). Effects of long-term summer deficit irrigation on 'Navelina' citrus trees. Agricultural Water Management. 169:140147. doi:10.1016/j.agwat.2016.02.028.

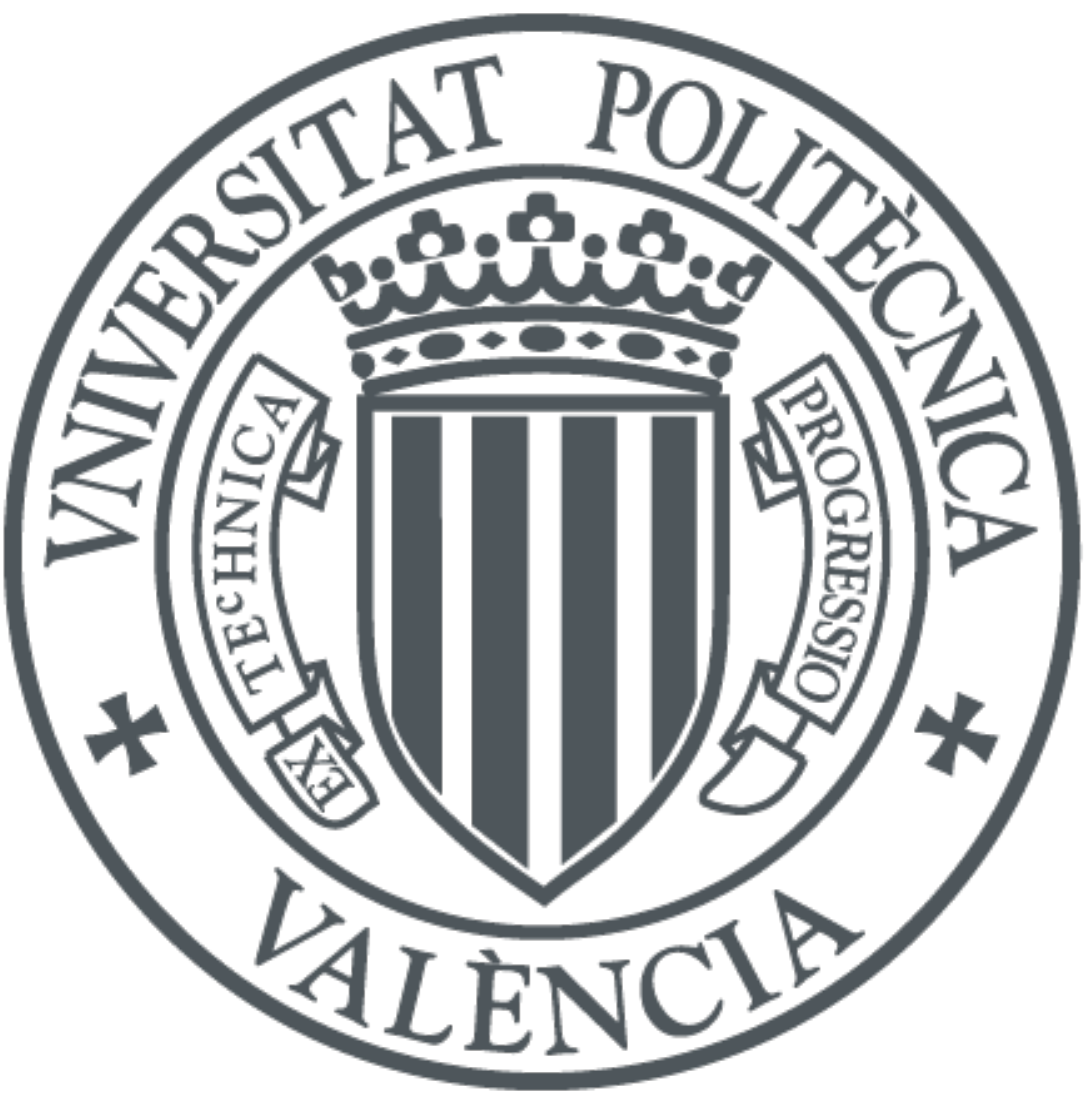

The final publication is available at

http://dx.doi.org/10.1016/j.agwat.2016.02.028

Copyright Elsevier Masson

Additional Information 


\section{Effects of long-term summer deficit irrigation on 'Navelina' citrus}

2

3

4

5

6

7

8

9

10

11

12

13

14

15

16

17

18

19

\section{trees}

María Gasque ${ }^{\mathrm{a}}$, Pau Martíb, Beatriz Granero ${ }^{\mathrm{c}}$ Pablo González-Altozano,*

Agricultural Water Management 169 (2016) 140-147

http://dx.doi.org/10.1016/j.agwat.2016.02.028

${ }^{a}$ Departamento de Física Aplicada. Universitat Politècnica de València. Camino de Vera s/n 46022 Valencia. mgasque@fis.upv.es

${ }^{b}$ Departament de Biologia, Àrea d'Enginyeria Agroforestal. Universitat de les Illes Balears. Cra. Valldemossa km 7.5, 07122 Palma de Mallorca. paumarpe@hotmail.es

${ }^{c}$ Instituto Valenciano de Investigaciones Agrarias (IVIA). CV-315, Km. 10.746113 Moncada (Valencia).granero_beagar@gva.es

${ }^{d}$ Departamento de Ingeniería Rural y Agroalimentaria. Universitat Politècnica de València. Camino de Vera s/n 46022 Valencia. pgaltozano@agf.upv.es

\section{ABSTRACT}

The effects of long-term summer deficit irrigation (RDI) strategies on 'Navelina' orange trees (Citrus sinensis L. Osbeck) were assessed in a drip-irrigated commercial orchard located in Senyera (Valencia, Spain). Three irrigation treatments were applied during five consecutive years (2007-2011): a control treatment, without restriction, and two RDI treatments, in which the water reduction was applied during the summer (initial fruit enlargement phase). During the first three seasons, the trees under the control treatment received $110 \%$ of the theoretically required irrigation dose (ID), and the RDI treatments received $40 \%$ and $60 \%$ of the full ID during the deficit period. During the last two years of the study, the control treatment was irrigated at $100 \%$ of the ID and the amount of water 
applied in the RDI treatments was additionally decreased $20 \%$ from the reduced ID of the preceding years. The crop's response to summer deficit irrigation was analysed in relation to tree water status, which was assessed by relying on midday stem water potential $\left(\Psi_{\text {st }}\right)$. The lowest $\Psi_{\text {st }}$ values were reached, as expected, at the end of the water deficit period and with the most stressed treatment. These minimum $\Psi_{\text {st }}$ values ranged between $-1.6 \mathrm{MPa}$ in 2008 and 2.5 MPa in 2010. In most occasions, the trees under RDI treatments showed a fast hydric recovery and had completely re-hydrated one week after restarting irrigation. Summer RDI treatments did not cause negative effects on either the amount or on the quality of the yield if the threshold value of $\Psi_{\mathrm{st}}=-2.0 \mathrm{MPa}$ was not surpassed. According to the results, it can be concluded that long-term RDI strategies may be applied successfully on Navelina orange trees during summer without negatively affecting the studied parameters while allowing water savings between $12 \%$ and $27 \%$.

38

Keywords: yield, fruit quality, regulated deficit irrigation, stem water potential, water use 40 efficiency. 


\section{Introduction}

44

Citrus are widely grown under diverse climatic conditions, including in semi-arid regions. Spain occupies one of the first places in the global ranking of citrus producing countries, with an average annual production exceeding 6.6 million t. Almost half of total production (about 3.5 million t) corresponds to the sweet orange group, in which the 'Navelina' orange is the most important cultivar, with a production of about 1.1 million $\mathrm{t}$ (MAGRAMA, 2015).

Water scarcity is an important problem in many areas of the world. It particularly affects the Mediterranean basin, with a semi-arid climate, scarce rainfall, hot summers, and a dry season that lasts for over three months. Irrigated agriculture is the sector with by far the largest water consumption. In Spain, about $72 \%$ of consumptive water is used for irrigation purposes (Frenken and Guillet, 2012).

Thus, increasing water scarcity demands a more efficient and optimized use of irrigation water. One of the most promising approaches for attaining this objective might be regulated deficit irrigation (RDI). RDI consists of reducing water supplies during certain stages of crop development, when yield and fruit quality might have a low sensitivity to water deficits, and providing normal irrigation doses during the rest of the season, especially during critical periods or phenological stages with a higher sensitivity to water deficits (Chalmers et al., 1986; Mitchell et al., 1984). Many works have proved the feasibility and effectiveness of this practice by reducing water use in tree crops with low or null impact on yield and fruit quality (e.g. Carr, 2012; Ruiz-Sánchez et al., 2010).

In order to adequately control the water stress caused by the application of RDI, it is important to monitor plant water status or soil water content appropriately. In this sense, stem 
water potential $\left(\Psi_{\text {st }}\right)$ seems to be a sensitive measure of plant water status (Choné et al., 2001; Ortuño et al., 2006). However, $\Psi_{\text {st }}$ is not easily measurable, and it is not suited for an automated irrigation scheduling. As an alternative or complement to tree water status monitoring, there are different techniques that allow for the continuous measurement of soil water content. Among others, the frequency domain reflectometry (FDR) probe, with multiple depth capacitance sensors (Fares and Polyakov, 2006; Paltineanu and Starr, 1997), has shown excellent performance so far. It is currently widely used for field applications as a decisionmaking tool for irrigation scheduling (Martí et al., 2013).

González-Altozano and Castel (2003a, 2003b, 2000, 1999) carried out several RDI tests on an experimental orchard of 'Clementina de Nules' citrus trees (Citrus clementina Hort ex Tan). Different levels of water restriction were compared in the main phenological periods of crop development, and the effects of water restriction on yield, fruit quality, and water use efficiency were assessed. They concluded that the effects of RDI treatments depend, among others, on the phenological period in which the water restriction is applied as well as on the degree of restriction applied. Specifically, they stated that moderate water reduction during the initial fruit enlargement phase, after the June fruitlet drop (July and August in the northern hemisphere), did not affect yield, fruit size, or quality, which allowed for significant water savings (8-22\%). These experiments also defined different pre-dawn leaf water potential $\left(\Psi_{\mathrm{pd}}\right)$ threshold values to avoid negative effects during the phenological period considered. Thus, summer $\Psi_{\text {pd }}$ should not surpass -1.2 $\mathrm{MPa}$, which corresponds to values of $\Psi_{\text {st }}$ around -1.9 MPa.

Most of the RDI studies carried out on citrus provide evidence of the advantages and benefits of reducing water application during summer. Citrus fruit has the capacity to accelerate growth after a water deficit period and thus be able to reach their potential size. This capacity, named compensatory fruit growth, is essential for the successful application of 
summer RDI strategies. However, Ballester et al. (2013) found that summer RDI treatments applied to Navel Lane Late citrus trees might prevent compensatory fruit growth after returning to irrigation at full dosage, depending on the duration and degree of severity of the plant water deficit. The latter study highlights the differences between cultivars in response to RDI, as well as the need for frequent monitoring of plant water status to avoid an excessive reduction of fruit weight that may affect yield.

The majority of RDI studies consider the effects of deficit irrigation treatments during two or three consecutive growing seasons. Other researches deal with the viability of longterm RDI strategies. These long-term RDI strategies may negatively affect yield capacity (Girona et al., 2005; Intrigliolo et al., 2013; Romero et al., 2004); however, some studies have reported substantial water savings without any reduction in yield or fruit size (Hueso and Cuevas, 2010; Johnson et al., 1992). It should be noted that, although there are several studies addressing the application of RDI to 'Navelina' citrus trees (García-Tejero et al., 2010; Aguado et al., 2012), to our knowledge, no investigation has considered the effects of longterm summer deficit irrigation with this cultivar.

The aim of this study is to analyse the feasibility of long-term summer RDI strategies in 'Navelina' citrus trees and the effects on yield, fruit quality, and vegetative growth during five consecutive years (2007-2011).

\section{Material and Methods}

\subsection{Soil and climate conditions}

The experiment was carried out during five consecutive growing seasons (2007-2011) on a commercial drip-irrigated plot of 1 ha in Senyera, Valencia $\left(39^{\circ} 3^{\prime} \mathrm{N}, 0^{\circ} 30^{\prime} \mathrm{W}, 23 \mathrm{~m}\right.$ a.s.1.), which was planted in 1982 with 'Navelina' orange trees (Citrus sinensis L. Osbeck) 
117 grafted on 'Cleopatra' mandarin trees (Citrus reshni Hort.) at a spacing of 5 x $5 \mathrm{~m}$, with an average ground cover of about $52 \%$.

The soil was deep sandy-loam with pebbles of alluvial origin, with an average organic matter content of $1.17 \%$, an electric conductivity $\left(\mathrm{EC}_{1-5}\right)$ of $0.14 \mathrm{dS} \mathrm{m} \mathrm{m}^{-1}, 39.1 \%$ of active $\mathrm{CaCO}_{3}$, and a $\mathrm{pH}$ in water $(1 / 25)$ of 8.0 . It was also poor in total nitrogen $(0.06 \%)$, available potassium (0.42 meq $\left.\mathrm{K}^{+} 100 \mathrm{~g}^{-1}\right)$ and phosphorus (20.67 $\mathrm{mg} \mathrm{P} \mathrm{kg}^{-1}$ Olsen). A more detailed description of the soil characteristics can be found in Martí et al. (2013).

The irrigation water used had an average electrical conductivity (at $25^{\circ} \mathrm{C}$ ) of $0.82 \mathrm{dS}$ $\mathrm{m}^{-1}$, with chloride content lower than $2 \mathrm{meq} \mathrm{Cl} \mathrm{L}^{-1}$ and a SAR value of 3.53 .

Climatic data were provided by the meteorological station belonging to the Irrigation Technology Service (STR) of the Valencian Institute for Agricultural Research (IVIA) in Villanueva de Castellón (Spain), less than $500 \mathrm{~m}$ from the experimental plot. The climate is Mediterranean semi-arid. The rainfall and the corresponding evaporative demand (ETo) for each year are summarized in Table 1. The average annual rainfall in the period 2000-2012 was $624 \mathrm{~mm}$, and the average annual ETo was $1083 \mathrm{~mm}$. The mean annual air temperature

132 during the same period was $17.1^{\circ} \mathrm{C}$.

Trees received fertilisation through the irrigation system at a non-limiting rate of 260$65-130 \mathrm{~kg} \mathrm{ha}^{-1}$ per year of $\mathrm{N}, \mathrm{P}_{2} \mathrm{O}_{5}$, and $\mathrm{K}_{2} \mathrm{O}$ respectively, split in weekly applications from April to October. Control of plagues and other cultural practices were carried out according to the usual local criteria in that area and were identical for all treatments. Trees were pruned in

1372009 and 2011.

\subsection{Irrigation treatments}

141 conditions $\left(\mathrm{ETc}=\mathrm{ETo} \cdot \mathrm{K}_{\mathrm{c}}\right.$ where $\mathrm{K}_{\mathrm{c}}$ is the crop coefficient) and effective precipitation $\left(\mathrm{E}_{\mathrm{p}}\right)$. 
142 Reference evapotranspiration (ETo) was determined by the FAO56 version of the Penman-

143 Monteith equation relying on daily average data from the meteorological station. The crop 144 coefficient $\left(\mathrm{K}_{\mathrm{c}}\right)$ was obtained for this location according to Castel (2005) based on the 145 percentage of shaded area in the plot (40.5-54.1\%). In the studied period, the different mean 146 seasonal values of $K_{c}$ values used were as follows: 0.54 in 2007, 0.61 in 2008, 0.59 in 2009, 147 and 0.54 in 2010 and 2011. The theoretical irrigation dose (ID) to ensure full irrigation was 148 calculated as ID $=\mathrm{ET}_{\mathrm{c}}-\mathrm{E}_{\mathrm{p}}$.

149 Three irrigation treatments were applied: a control treatment, irrigated without 150 restriction throughout the whole year, and two RDI treatments (T1 and T2), which received 151 the same amount of water as the control except during the restriction period (the initial fruit 152 enlargement phase, from mid-July to early September). The established irrigation treatments, 153 the duration of each one, and the dose applied throughout each growing season are 154 summarized in Table 2.

155 During the first three years $(2007,2008$, and 2009), the control treatment was irrigated 156 at $110 \%$ of full ID. T1 and T2 received $40 \%$ and $60 \%$ of full ID during the restriction period, 157 respectively.

158 The control treatment was irrigated at $100 \%$ of ID in the last two seasons (2010 and 159 2011). In 2010, the amount of water applied in the RDI treatments was reduced by an 160 additional $20 \%$. Thus, the $\mathrm{T} 1$ and $\mathrm{T} 2$ treatments received during the restriction period $32 \%$ 161 and $48 \%$ of ID. Finally, in 2011 the data provided by the FDR probes were used for irrigation 162 scheduling of $\mathrm{T} 2$ and as an additional information source of the amount of water applied to

163 T1. Accordingly, the T2 treatment was scheduled in order to maintain soil water content in 164 the zone between $0-60 \mathrm{~cm}$ of the soil depth in the range $50-60 \mathrm{~mm}$ during the restriction 165 period and between $70-80 \mathrm{~mm}$ during the rest of the year. The T1 treatment received $40 \%$ of 166 ID during the restriction period and $100 \%$ of ID during the rest of the year. In this treatment, 
167 the irrigation water applied was also monitored and adjusted depending on the soil water

168 content measured with the FDR probe in the zone 0-60 $\mathrm{cm}$ of soil depth. Thereby, the soil 169 water content was kept above $50 \mathrm{~mm}$ in the zone between $0-60 \mathrm{~cm}$ of soil depth during the 170 restriction period and above $80 \mathrm{~mm}$ during the rest of the year.

171 Considering the five years, the irrigation treatments T1, T2, and control received, 172 respectively, an average of $42.2 \%, 58.4 \%$ and $101.2 \%$ of ID during the water deficit periods.

173 The experimental design was based on a randomised complete block with three 174 replicates per treatment. Each experimental unit consisted of a minimum of three rows with 17510 trees per row, using perimeter trees as guard. Thus, yield and fruit quality parameters were 176 determined from a minimum of eight trees per experimental unit. Further details about the 177 distribution of each replicate of the applied treatments can be found in Gasque et al. (2010).

178 The irrigation system consisted of a double line (1.8 $\mathrm{m}$ spaced) of drip-irrigation with 179 eight self-regulating drippers per tree with an average flow of $7.4 \mathrm{~L} \mathrm{~h}^{-1}$ per dripper. Irrigation 180 frequency, identical for all treatments, ranged between six irrigations per week during the 181 summer and two irrigations per week during the winter. The amount of applied water was 182 measured through weekly water-meter readings for each irrigation replicate.

\subsection{Tree water status measurements}

Midday stem water potential $\left(\Psi_{\mathrm{st}}\right)$ was measured weekly around $12 \mathrm{~h}(\mathrm{GMT})$ during 186 the growing season and less frequently during the winter using a 'Scholander' type (SF-Pres18735 by Solfranc Tecnologías, S.L.) pressure chamber, following the procedures described by 188 Turner (1981). $\Psi_{\text {st }}$ was measured for a minimum of two south oriented mature leaves per tree, 189 which had been wrapped in bags at least two hours before, and for two trees per individual 190 plot for each of the three replicates per treatment. 


\subsection{Fruit and shoot growth}

Sixteen fruit per tree (four in each cardinal quadrant) were selected and tagged from three trees per treatment (one per replicate). Equatorial fruit diameter was measured weekly every year from the beginning of July until harvest. In the same trees, shoot elongation was determined during the first growth flush in the spring of 2011 on samples of 16 shoots per tree (four shoots per cardinal quadrant) from 10 March to 23 May, every 7-14 days.

On the other hand, fresh fruit weight (FW) and dry fruit weight (DW) were determined each season in four fruit randomly selected per replicate in three moments: before restriction (BR), at the end of the restriction (ER), and at harvest $(\mathrm{H})$.

With the aim of verifying that RDI treatments started after the end of the 'June drop' as well as to check the treatments' effects on fruit abscission, the number of fruit fallen were registered weekly each season in two trees per replicate from fruit-set till harvest.

\subsection{Yield and fruit quality}

At the end of each season during the commercial harvest, the yield and its components were determined in at least eight trees per replicate ( 24 trees per treatment). The average fruit weight was evaluated by counting the number of fruit in a minimum of eight boxes per individual plot, previously weighed (about $20 \mathrm{~kg} / \mathrm{box}$ ). Fruit quality variables: peel, juice, sugars (Total Soluble Solids, TSS), acid content (Titratable Acidity, TA), soluble solids, pH, and vitamin $\mathrm{C}$, were determined at harvest with samples of at least nine fruit per individual plot following the procedures described by González-Sicilia (1951).

Water use efficiency (WUE) was determined as the ratio between yield and total applied water (irrigation + rainfall). 
Trunk perimeter (TP) was measured at marked sections above the graft (about $30 \mathrm{~cm}$ above the ground) on eight trees per replicate at the beginning and at the end of each season. Moreover, tree size, percentage of shaded area and volume of the tree top were also 220 determined in the same trees.

\subsection{Soil water content}

During the last two years (2010-2011) the volumetric water content in the soil profile was monitored every 30 minutes using a multisensor capacitance probe (ENVIROSCAN, Sentek Sensor Technologies) based on FDR. Therefore, three FDR probes were installed in July 2009 on the north side of one tree per treatment, placed $25 \mathrm{~cm}$ from the emitter's line. The capacitance probes were properly installed within the active root system zone. Each probe presented four sensors. The first three sensors, located at 10, 30, and $50 \mathrm{~cm}$ of depth, covered practically $90 \%$ of the active root system (estimated during probe installation), while the fourth was outside of this zone $(70,80$, and $60 \mathrm{~cm}$ depth in the probes for treatments $\mathrm{T} 1$,

231 T2, and the control, respectively). More details about the installation of these probes can be 232 found in Martí et al. (2013).

\subsection{Statistical analysis}

Statistical analyses were performed using the SPSSv16 package (SPSS Inc., Chicago IL) with a one-way analysis of variance (ANOVA), given that data fit the assumptions of the parametric tests (test K-S). Differences among treatments were studied with the Tukey test $(95 \%)$ 


\section{Results and discussion}

The evolution of midday stem water potential $\left(\Psi_{\mathrm{st}}\right)$, fruit growth, and the fruit's relative diameter in relation to the control are depicted in Fig. 1 (period 2007-2009) and Fig. 2 (period 2010-2011). Rainfall and the ETo evolution during each period are also shown in these figures. The amount of water applied in each irrigation treatment, water use efficiency values (WUE), as well as yield parameters and its components are summed up in Table 3.

During the period 2007-2009, the $\Psi_{\text {st }}$ values in control trees were around $-0.9 \mathrm{MPa}$.

Although very low $\Psi_{\text {st }}$ values were occasionally measured, e.g. end of 2007 (around -1.65 $\mathrm{MPa}$ ), in general, it can be accepted that the $\Psi_{\text {st }}$ values in the control treatment were within normal midday stem water potential ranges of well-irrigated citrus trees (Ballester et al., 2014; Syvertsen and Albrigo, 1980).

The lowest $\Psi_{\text {st }}$ values reached in deficit treatments occurred on the $31^{\text {th }}$ August of 2007 and 2008 (around -1.71 and $-1.60 \mathrm{MPa}$, respectively); both values were registered during the most severe restriction treatment (T1) (Fig. 1C). These $\Psi_{\text {st }}$ values were higher (less negative) than the suggested threshold values for citrus under summer water deficits (González-Altozano and Castel, 1999, 2003a), and they did not suggest significant water stress levels according to Domingo et al. (1996).

Based on the $\Psi_{\text {st }}$ values observed during the period 2007-2009 both in the RDI and control treatments, and also on the results obtained that will be discussed later, the irrigation dose applied during the period 2010-2011 was reduced (100\% of full ID) from that applied in the preceding growing seasons (110\% of full ID) (Table 2).

Despite this reduction, the evolution of tree water status for all treatments showed a similar trend during the five years of study. The $\Psi_{\text {st }}$ values observed for the control trees during the period 2010-2011 were around -1.0 MPa. These values indicate that the control 
trees were always fully irrigated, although the irrigation dose that was applied was

266 additionally reduced. Moreover, before the restriction period, hardly any differences with respect to the control in the $\Psi_{\text {st }}$ values of the RDI treatments were detected, which maintained a high level (around -1.0 MPa), indicating a total absence of water stress.

The evolution of the $\Psi_{\text {st }}$ reflected well the restriction periods as well as some unexpected water cut-offs that occurred during November and December of 2007 and September and October of 2008. In both years, these water cut-offs produced rapid and important drops of $\Psi_{\text {st }}$ in autumn for all treatments.

In all seasons, after the beginning of the restriction, a slow and continuous $\Psi_{\text {st }}$ drop was indicative of the progression of the water deficit period during the RDI treatments. The minimum potential values were reached at the end of this period every year, and, as might be expected, the higher the restriction level, the lower the values dropped. At the end of the restriction period of 2010 , minimum the $\Psi_{\text {st }}$ values for the five years were reached $(-2.5 \mathrm{MPa}$ in the $\mathrm{T} 1$ treatment and -2.1 MPa in T2) (Fig. 2C). In all seasons except for 2010, one week after restarting the full ID, trees of both RDI treatments had completely re-hydrated. In 2010, 280 the subsequent hydric recovery of the trees under RDI treatments was faster for T2 and much 281 slower for the more restrictive T1. This recovery rate, together with the degree of stress 282 suffered, affected both the size and quality of the fruit, as will be discussed below. The use of data provided by the FDR probes in 2011 to schedule irrigation for T2 and to better adjust the applied dose for T1 appeared to be useful to avoid detrimental stress levels. Consequently, the obtained potential values were higher (less negative) than those reached in 2010, causing 286 lower hydric stress.

During the restriction period, a slight deceleration of fruit growth was observed for the deficit treatments during all years excepting 2008 (Figs. 1B and 2B). However, fruit diameter 
affecting the final fruit weight (Table 3). In 2009, 2010, and 2011, these differences did not 291 reach statistical significance, but a slower growth of fruit under T1 and T2 was observed. The rapid hydric recovery observed in deficit treatments after finishing the restriction was reflected in a higher relative growth of fruit under these treatments in comparison to the control (Figs. 1D and 2D). This fruit growth acceleration, known as compensatory fruit growth, is usual when irrigation at full dose restarts after a water restriction period (Chalmers et al., 1986; González-Altozano and Castel, 2003a; Mitchell and Chalmers, 1982; RuizSánchez et al., 2000). Compensatory fruit growth was not found in fruit under the RDI treatments in 2008. This was in accordance with the absence, during this year, of growth deceleration.

In 2011, the trees under the RDI treatments showed a rapid hydric recovery at the end 301 of the restriction, a situation which is in accordance with the more rapid fruit growth under stressed treatments (Fig. 2D). This finding notes once again the importance of recovering and maintaining an adequate water status in the trees after the restriction and until harvest, which allows for fruit growth compensation. The minimum potential values reached by trees of the RDI treatments in $2011\left(\Psi_{\mathrm{st}}=-1.95 \mathrm{MPa}\right.$ in $\mathrm{T} 1$ and $\Psi_{\mathrm{st}}=-1.6 \mathrm{MPa}$ in $\left.\mathrm{T} 2\right)$, did neither cause negative effects on the production nor on the quality of harvest (Table 3).

Regarding fruitlet drop, it was similar for all treatments in all of the studied years (results not shown). In all growing seasons, the 'June drop' had concluded by the end of June (DOY 182) and always before the start of the restriction treatments. The end of water restriction neither produced appreciable fruitlet drop nor flowering for any treatment or year.

311 In addition, the irrigation restrictions neither affected the flowering process nor the growth 312 flush after June (Fig. 2). Finally, as depicted in Fig. 2B, shoot growth of the first flush was 313 clearly separated in time from the period of fruit growth and occurred long before the 
314 restriction period started. Therefore, the required conditions for achieving successful 315 implementation of RDI in Navelina citrus trees were fulfilled.

316 Attending to the influence of the irrigation treatments on yield and its components 317 during the entire period (Table 3), significant differences were observed in yield between 318 years $(\mathrm{p}<0.05)$ ranging from $134.4 \mathrm{~kg} /$ tree in 2008 to $43.3 \mathrm{~kg} /$ tree in 2009 , with an average 319 of $79.8 \mathrm{~kg} /$ tree for the control treatment. These differences were mainly due to the number of 320 fruit/tree, ranging in control trees from 185 fruit/tree in the least productive year (2009) to 593 321 fruit/tree in the most productive one (2008). Differences in average fruit weight were not so marked and ranged from $231.6 \mathrm{~g}$ (in 2008) to $296.0 \mathrm{~g}$ (in 2007). It should be noted that the aforementioned slowdown in fruit growth of stressed trees was observed during all years 324 except 2008, while it had been expected that due to the higher crop load, the effects of water stress in 2008 should have been more evident. The reported results indicate that the effects of water deficit on the fruit growth rate were of minor importance, given that only small differences between treatments were detected in this parameter, even in 2010, when the lowest $\Psi_{\text {st }}$ values for the five years were registered. However, there were differences in the pattern of fruit growth between years, indicating that, with moderate levels of stress (such as

330 those suffered by trees during the present study), the number of fruit/tree has greater influence on the production and on the final fruit size than the level of stress reached.

The RDI treatments yielded systematically higher production than the control, although these differences were only significant $(p<0.05)$ in the growing seasons 2009 and

334 2011. Different results were reported by García-Tejero et al. (2010 and 2012) in Navelina 335 citrus trees, in a study in which more severe water stress was applied during the flowering, 336 fruit growth and maturity phases; in this study the number of fruit per tree was significantly 337 lower in trees held under deficit irrigation. The response to water stress may therefore vary 
depending on the duration and severity of treatments, as stated by other researchers (Ballester et al. 2013; Treeby et al. 2007).

A higher number of fruit per tree usually involves a smaller fruit size. However, this was not the general trend in the present study. Here, the trees under deficit treatments produced in some cases (e.g. T2 in 2007 and T1 in 2009) more fruit per tree than the control trees $(\mathrm{p}<0.05)$, while no differences were found in average fruit weight (Table 3). Moreover, 344 in 2011, the fruit size under T1 and T2 was very acceptable and, at the same time, higher than 345 the annual average (246.2 g), while these treatments yielded many more fruit per tree than the control $(\mathrm{p}<0.05)$. Both deficit treatments returned significantly higher production than the 347 control, despite having reached, as aforementioned, a minimum potential value of $\Psi_{\text {st }}=-1.95$ $348 \mathrm{MPa}$ in the most stressed treatment.

349 The higher number of fruit per tree in trees under deficit irrigation occurred after the 350 growing seasons in which lower $\Psi_{\text {st }}$ values were reached, and/or after certain unscheduled water stress levels during autumn. Therefore, results seem to indicate that trees that had 352 previously suffered from stress could be more sensitive to an occasional shortage of water in 353 autumn, which might have favoured to some extent the fruiting-flowering-fruit-set process. It 354 should be pointed out that no significant differences were observed between treatments with respect to the variables that define tree size (trunk perimeter, percentage of shaded area, 356 volume of the tree top) either before the beginning of this study or any of the five years during 357 the study. Although on average, the size of the trees under RDI was slightly higher than that 358 of the control trees (6-12\% in volume of tree top; $3-4 \%$ in trunk perimeter), this small 359 difference does not explain the large differences found in yield. The relationship of fresh to dry weight accumulated in the fruit (FW/DW) for each 361 treatment is shown in Table 4. Before restriction (BR), it was verified that this relationship 362 was similar between treatments each year. When the restriction period was complete (ER), the 
relationship FW/DW was lower for the RDI treatments than for the control during all the

364 seasons, and the differences were statistically significant $(\mathrm{p}<0.05)$ in four of the five years.

365 These results indicate that the RDI fruit still accumulated dry matter during the restriction

366 period, thus reducing FW in comparison to the control treatment (Table 4). As no differences

367 in the FW/DW relationship were detected before restriction, the differences found when the

368 restriction period was concluded could be attributed to the treatments that had been applied.

369 Once restarting full irrigation, compensatory fruit growth under RDI treatments occurred at 370 the expense of accumulated dry matter. Therefore, these differences tend to disappear at 371 harvest $(\mathrm{H})$.

Only during 2010, when the highest stress levels were reached in RDI treatments, no

differences were observed in dry matter accumulation in the fruit at the end of the restriction period (ER). There was also no compensatory fruit growth, and at harvest, the fruit of these trees tended to be smaller than those under the control (Table 3). The differences were significant $(\mathrm{p}<0.05)$ in treatment $\mathrm{T} 1$, with the highest concentration of dry matter (lower ratio FW/DW), indicating that the harvest took place when these fruit were less hydrated; they also probably still had a certain capacity for growth.

Table 5 shows the influence of irrigation treatments on fruit quality. In contrast to other RDI studies (Ballester et al., 2014; García-Tejero et al., 2010; Yakushiji et al., 1996) that found a significant increase in TSS and TA under RDI strategies, in this study, no significant differences were found in comparison to the control in any of the studied fruit quality parameters with the exception of the lower juice content in the fruit under T1 in 2010. The higher concentration of sugar and soluble solids reported in other studies could be due to the longer duration of the stress period or to the higher levels of water stress suffered. Regarding to the juice content, it was on average (excluding the 2010 season) $47.9 \%$ of the fruit weight, similar to the normal values for this variety $(48.2 \%$ according to 
Sanchotene Gonçalves, 1998), and very similar to those found by other authors in 'Lane Late'

389 citrus fruit (Pérez-Pérez et al., 2009). In 2010, the fruit showed lower juice content values 390 than those cited in the literature and much lower values than in other seasons. In 2010, the

391 fruit under the RDI treatments were also the smallest ones within the five years. These 392 differences in juice content and fruit size were especially noticeable in the T1 treatment after 393 having reached the lowest values of stem water potential $\left(\Psi_{\mathrm{st}}=-2.5 \mathrm{MPa}\right)$. This result 394 provides evidence that the stress level reached in this treatment during 2010 exceeded the 395 recommended level. However, the T2 treatment, after having reached a minimum value of $\Psi_{\text {st }}$

$396=-2.1 \mathrm{MPa}$, did not affect the production or the quality of the fruit. Even though the fruit of 397 this treatment were smaller than those of the control, the differences were not significant, 398 indicating the proximity to the stress level to avoid negative effects.

In 2011, when less water was applied, although distributed in a more suitable way than in 2010 as reflected in the $\Psi_{\text {st }}$ evolution (Fig. 2), production under RDI was much higher than under the control due to a higher number of fruits per tree. Although fruit size was also affected, this effect was relatively minor given that the final fruit size in the more stressed treatment (T1) was higher (no significant differences) to that of the control average in the 404 entire period. In addition, the internal quality of the fruit was not affected, indicating that the 405 RDI strategy adopted this year was more appropriate (minimum potential $\Psi_{\text {st }}=-1.95 \mathrm{MPa}$ under T1). All these results suggest that $\Psi_{\mathrm{st}}=-2.0 \mathrm{MPa}$ might be considered a potential 407 threshold value which should not be exceeded to avoid the negative effects of applying RDI 408 in summer.

409 The most suitable parameter for reflecting the effect of irrigation treatments on 410 vegetative growth was the increment in trunk perimeter $(\Delta \mathrm{TP})$. The values of $\Delta \mathrm{TP}$ from 2007 411 to 2011 were $0.12,0.10$, and 0.13 meters in $\mathrm{T} 1, \mathrm{~T} 2$, and the control, respectively. No 412 statistical differences were found between treatments, showing that water restriction did not 
413 affect trunk growth. This finding is contrary to those commonly found in experiments carried 414 out with different tree crops, specifically citrus, and could be due to the larger development 415 and age of the trees. In the present study, the trees were 25 years old at the beginning of the 416 experiment, whereas in other studies, trees were 8-10 years old (Clementina de Nules, 417 Ballester et al., 2014, 2011; González-Altozano and Castel, 2000), and seven years old (Navel 418 Lane Late, Ballester et al., 2013). In these studies with younger trees, it was verified that 419 trunk growth under RDI was lower than under full irrigation. Probably, the lower growth 420 potential due to the size and age of the trees in the present study prevented the RDI treatments 421 from affecting the growth of the trunk. Hence, with the reported results, after five years of 422 study, it is not expected that the application of long-term summer RDI strategies have 423 significant effects on production, which is ultimately supported by trunk and roots (tree size 424 and height).

Although in citrus, water use efficiency (WUE, Table 3) may be affected by the timing and fruit stage where the water restriction is applied (Carr, 2012), in this case, it is evident that summer RDI treatments provided significantly higher WUE than the control treatment, as is generally associated (Fereres and Soriano, 2007), which contrasts with the results shown in other experiments with citrus trees (Ballester et al., 2014; García-Petillo and Castel, 2004).

\section{Conclusions}

Based on the results derived from this study, long-term RDI strategies during the summer (initial phases of fruit enlargement) can be successfully applied in commercial Navelina citrus trees. 
of study, water savings between $12 \%$ and $27 \%$ resulted in only a slight reduction in average

439 fruit weight in the RDI treatments, in the more restrictive cases, which was balanced with a 440 higher yield.

FDR probes were very effective for adjusting the applied doses to avoid detrimental stress levels. In the context of this work, using FDR probes could be considered a preliminary step for achieving more accurate irrigation scheduling.

According to the obtained results, the application of summer RDI in Navelina is much more cost-effective than the traditional full doses under the boundaries tested. Therefore, the practical and reliable information provided in this work could be employed for optimizing water management in commercial applications.

\section{Acknowledgements}

This experiment was funded by the company Técnicas Valencianas del Agua S.A. (TECVASA), with financial support from the Conselleria de Agricultura, Pesca $y$ Alimentación de la Generalitat Valenciana for this purpose (DOCV 5493, 19 April 2007, no. exp.: 2007TAHAVAL00018).

\section{References}

Aguado, A., Frías, J., García-Tejero, I., Romero, F., Muriel, J.L., Capote, N., 2012. Towards the improvement of fruit-quality parameters in citrus under deficit irrigation strategies. ISRN Agronomy 2012, 1-10.

Ballester, C., Castel, J., El-Mageed, T.A.A., Castel, J.R., Intrigliolo, D.S., 2014. Long-term response of "Clementina de Nules" citrus trees to summer regulated deficit irrigation. Agr. Water Manage. 138, 78-84. citrus trees to regulated deficit irrigation: yield components and fruit composition. Irrigation Sci. 31, 333-341. 
Ballester, C., Castel, J., Intrigliolo, D.S., Castel, J.R., 2011. Response of Clementina de Nules citrus trees to summer deficit irrigation. Yield components and fruit composition. Agr. Water Manage. 98, 1027-1032.

Carr, M.K.V, 2012. The water relations and irrigation requirements of citrus (Citrus spp.): a review. Exp. Agr. 48, 347-377.

Castel, J.R., 2005. Evapotranspiración, balance de energía y coeficiente de cultivo de plantaciones de cítricos en Valencia. Monografías INIA 17, 210-219.

Chalmers, D.J., Burge, G., Jerie, P.H., Mitchell, P.D., 1986. The mechanism of regulation of Bartlett pear fruit and vegetative growth by irrigation withholding and regulated deficit irrigation. J. Am. Soc. Hortic. Sci. 111, 904-907.

Choné, X., van Leeuwen, C., Dubourdieu, D., Gaudillère, J.P., 2001. Stem water potential is a sensitive indicator of grapevine water status. Ann. Bot. 87, 477-483.

Domingo, R., Ruiz-Sánchez, M.C., Sánchez-Blanco, M.J., Torrecillas, A., 1996. Water relations, growth and yield of Fino lemon trees under regulated deficit irrigation. Irrigation Sci. 16, 115-123.

Fares, A., Polyakov, V., 2006. Advances in crop water management using capacitive water sensors. Adv. Agron. 90, 43-77.

Fereres, E., Soriano, M.A., 2007. Deficit irrigation for reducing agricultural water use. J. Exp. Bot. 58, 147-159.

Frenken, K., Guillet, V., 2012. Irrigation water requirement and water withdrawal by country, FAO-AQUASTAT Thecnical Report. November 2012.

García-Petillo, M., Castel, J.R., 2004. The response of Valencia orange trees to irrigation in Uruguay. Span. J. Agric. Res. 2, 429-443.

García-Tejero, I., Romero-Vicente, R., Jiménez-Bocanegra, J.A., Martínez-García, G., DuránZuazo, V.H., Muriel-Fernández, J.L., 2010. Response of citrus trees to deficit irrigation during different phenological periods in relation to yield, fruit quality, and water productivity. Agr. Water Manage. 97, 689-699.

García-Tejero, I., Durán-Zuazo, V.H., Arriaga-Sevilla, J., Muriel-Fernández, J.L., 2012. Impact of water stress on citrus yield. Agron. Sustain. Dev. 32, 651-659.

Gasque, M., Granero, B., Turegano, J.V, González-Altozano, P., 2010. Regulated deficit irrigation effects on yield, fruit quality and vegetative growth of "Navelina"citrus trees. Span. J. Agric. Res. 8(S2), S40-S51.

Girona, J., Mata, M., Marsal, J., 2005. Regulated deficit irrigation during the kernel-filling period and optimal irrigation rates in almond. Agr. Water Manage. 75, 152-167. 
González-Altozano, P., Castel, J.R., 2003a. Riego deficitario controlado en“"Clementina de Nules”. I. Efectos sobre la producción y la calidad de la fruta. Span. J. Agric. Res. 1, 8192.

González-Altozano, P., Castel, J.R., 2003b. Riego deficitario controlado en“" Clementina de Nules”. II. Efectos sobre el crecimiento vegetativo. Span. J. Agric. Res. 1, 93-101.

González-Altozano, P., Castel, J.R., 2000. Regulated deficit irrigation in "Clementina de Nules” citrus trees. II: Vegetative growth. J. Hortic. Sci. Biotech. 75, 388-392.

González-Altozano, P., Castel, J.R., 1999. Regulated Deficit Irrigation in "Clementina de Nules" citrus trees. I. Yield and fruit quality effects. J. Hortic. Sci. Biotech. 74, 706-713.

González-Sicilia, E., 1951. Características de los frutos de algunas variedades de agrios. Boletín INIA 23, 135-209.

Hueso, J.J., Cuevas, J., 2010. Ten consecutive years of regulated deficit irrigation probe the sustainability and profitability of this water saving strategy in loquat. Agr. Water Manage. 97, 645-650.

Intrigliolo, D.S., Ballester, C., Castel, J.R., 2013. Carry-over effects of deficit irrigation applied over seven seasons in a developing Japanese plum orchard. Agr. Water Manage. 128, 13-18.

Johnson, R.S., Handley, D.F., DeJong, T.M., 1992. Long-term response of early maturing peach trees to postharvest water deficits. J. Am. Soc. Hortic. Sci. 117, 881-886.

MAGRAMA, 2015. Ministerio de Agricultura, Alimentación y Medio Ambiente. Anuario de Estadística. www.magrama.gob.es/es/estadistica/temas/publicaciones/anuario-deestadistica/. [accesed July 2015].

Martí, P., Gasque, M., González-Altozano, P., 2013. An artificial neural network approach to the estimation of stem water potential from frequency domain reflectometry soil moisture measurements and meteorological data. Comput. Electron. Agr. 91, 75-86.

Mitchell, P.D., Chalmers, D.J., 1982. The effect of reduced water supply on peach tree growth and yields. J. Am. Soc. Hortic. Sci. 107, 853-856.

Mitchell, P.D., Jerie, P.H., Chalmers, D.J., 1984. The effects of regulated water deficits on pear tree growth, flowering, fruit growth, and yield. J. Am. Soc. Hortic. Sci. 109, 604606.

Ortuño, M.F., García-Orellana, Y., Conejero, W., Ruiz-Sánchez, M.C., Mounzer, O., Alarcón, J.J., Torrecillas, A., 2006. Relationships between climatic variables and sap flow, stem _water potential and maximum daily trunk shrinkage in lemon trees. Plant Soil 279, 229-242.

Paltineanu, I.C., Starr, J.L., 1997. Real-time soil water dynamics using multisensor capacitance probes: laboratory calibration. Soil Sci. Soc. Am. J. 61, 1576-1585. 
Pérez-Pérez, J.G., Robles, J.M., Botía, P., 2009. Influence of deficit irrigation in phase III of fruit growth on fruit quality in "lane late"sweet orange. Agr. Water Manage. 96, 969974.

Romero, P., Botia, P., Garcia, F., 2004. Effects of regulated deficit irrigation under subsurface drip irrigation conditions on vegetative development and yield of mature almond trees. Plant Soil 260, 169-181.

Ruiz-Sánchez, M.C., Domingo, R., Castel, J.R., 2010. Review. Deficit irrigation in fruit trees and vines in Spain. Span. J. Agric. Res. 8 (S2), S5-S20.

Ruiz-Sánchez, M.C., Torrecillas, A., Pérez-Pastor, A., Domingo, R., 2000. Regulated deficit irrigation in apricot trees. Acta Hortic. 537, 759-766.

Syvertsen, J.P., Albrigo, L.G., 1980. Seasonal and diurnal citrus leaf and fruit water relations.

Sanchotene Gonçalves, A., 1998. Características y desarrollo de las principales variedades de cítricos producidas y comercializadas en España: variedades de naranjo: grupo Navel. Levante Agrícola Rev. Int. cítricos 343, 131-140.

Treeby, M.T., Henriod, R.E., Bevington, K.B., Milne, D.J., Storey, R., 2007. Irrigation Bot. Gaz. 144, 440-446. management and rootstock effects on navel orange [Citrus sinensis (L.) Osbeck] fruit quality. Agr. Water Manage. 91, 24-32.

Turner, N.C., 1981. Techniques and experimental approaches for the measurement of plant water status. Plant Soil 58, 339-366.

Yakushiji, H., Nonami, H., Fukuyama, T., Ono, S., Takagi, N., Hashimoto, Y., 1996. Sugar accumulation enhanced by osmoregulation in Satsuma mandarin fruit. J. Am. Soc. Hortic. Sci. 121, 466-472. 


\section{LIST OF FIGURE CAPTIONS}

Fig. 1. Evolution during 2007, 2008 and 2009 of: ETo and Rainfall (A), fruit diameter (B), midday stem water potential (C), and relative diameter fruit growth of RDI treatments in relation to the control (D. The vertical dotted lines show the beginning and the end of the restriction period. Harvest dates were $8^{\text {th }}$ January, $17^{\text {th }}$ November and $18^{\text {th }}$ December for the first, second and third season, respectively.

Fig. 2. Evolution during 2010 and 2011 of: ETo and Rainfall (A), fruit growth (20102011) and shoot growth of the first flush (2011) (B), midday stem water potential (C), and relative diameter fruit growth of RDI treatments in relation to the control (D). The vertical dotted lines show the beginning and the end of the restriction period. Harvest dates were $26^{\text {th }}$ January 2011 and $13^{\text {th }}$ January 2012 , respectively. 


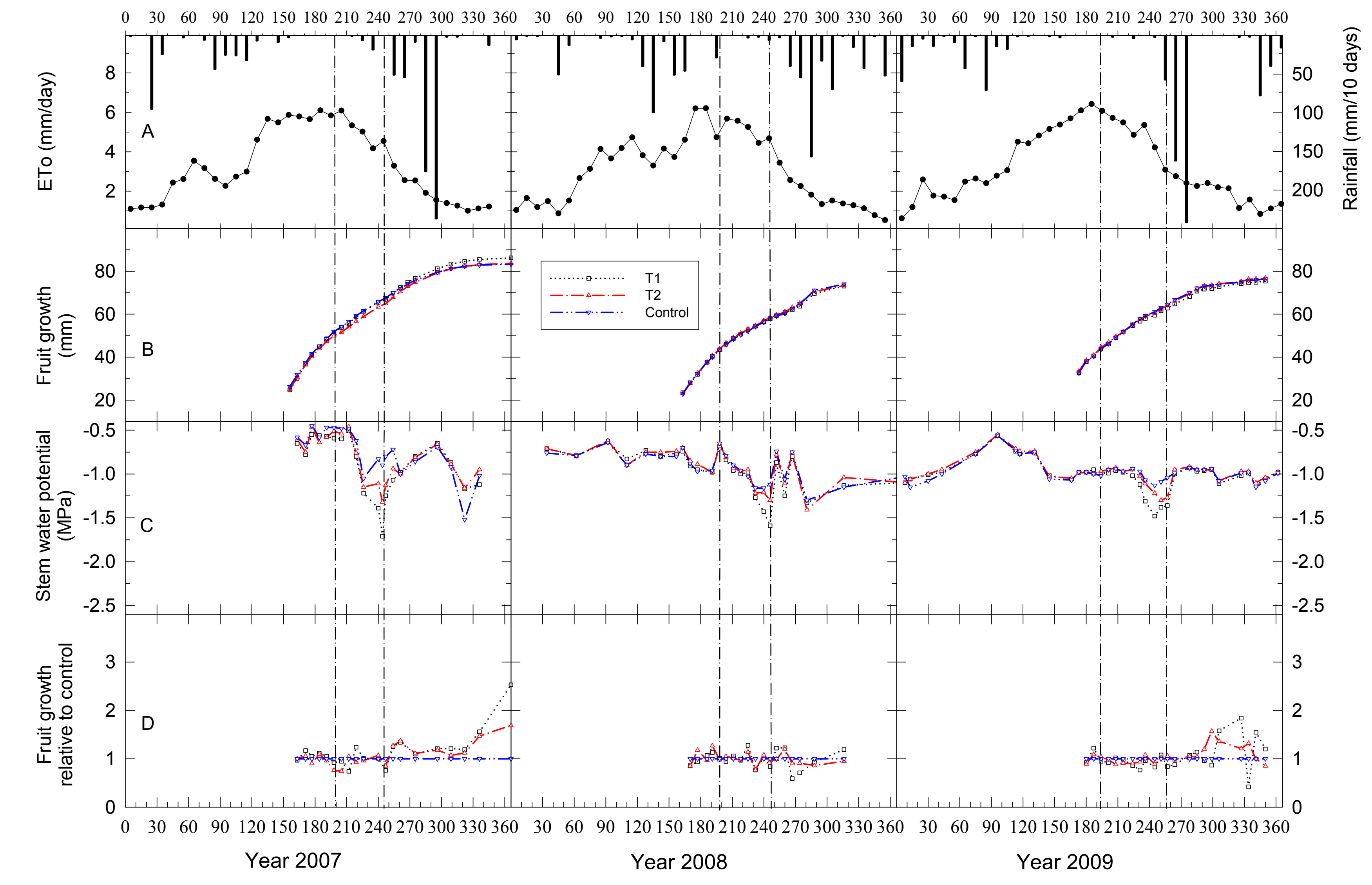
. . 


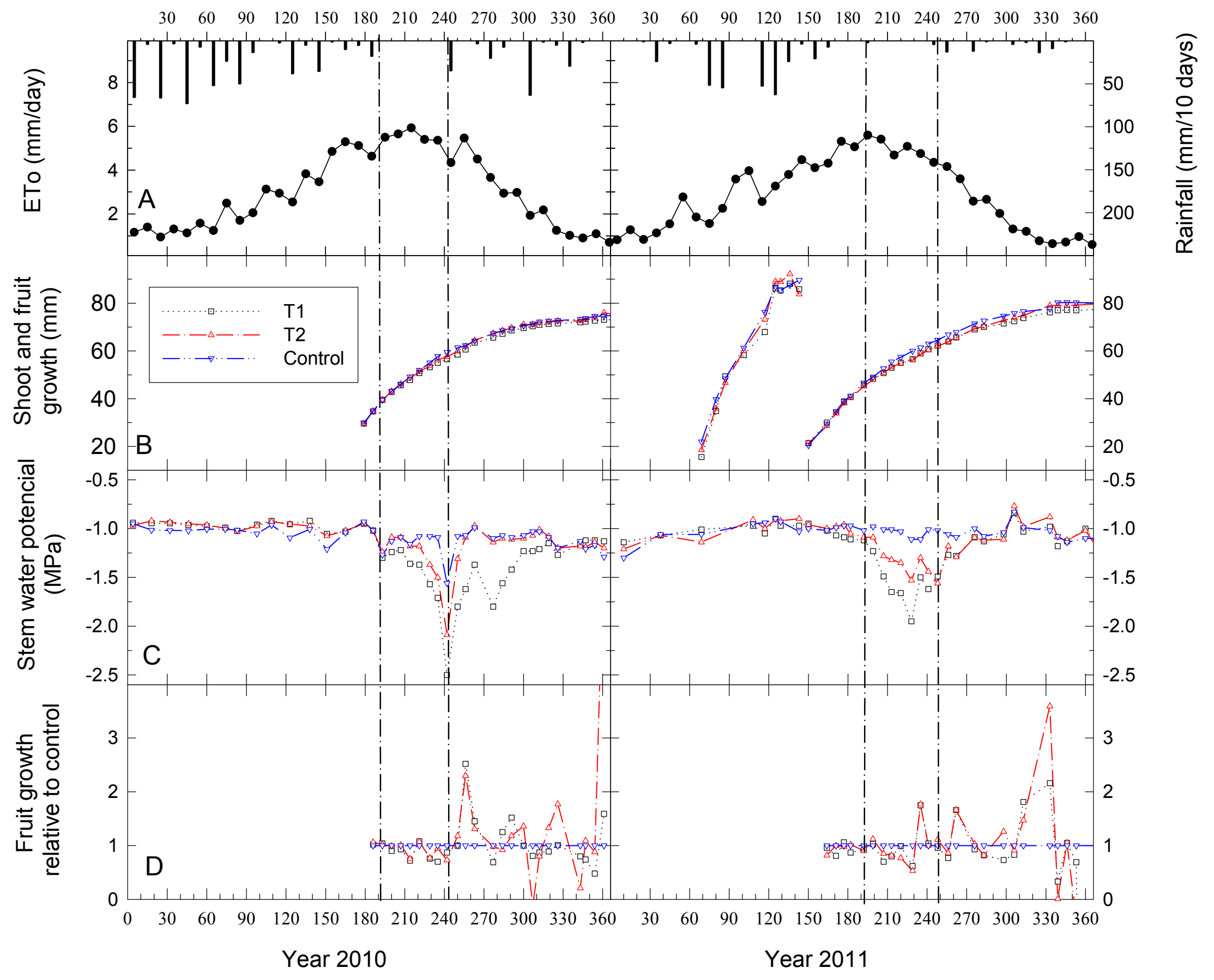




\section{LIST OF TABLE CAPTIONS}

Table 1. Rainfall and evaporative demand (ETo) registered at the meteorological station nearest to the experimental plot during the studied period.

Table 2. Irrigation treatments applied during the experimental period (2007 to 2011).

Table 3. Amount of water applied in each irrigation treatment, yield and its components, and water use efficiency (WUE).

Table 4. Relation FreshWeight/DryWeight (FW/DW), before restriction (BR), at the end of the restriction $(\mathrm{ER})$ and at harvest $(\mathrm{H})$ in each treatment and year.

Table 5. Fruit quality parameters of 'Navelina' citrus trees per treatment and year. 
2 Table 1. Rainfall and evaporative demand (ETo) registered at the meteorological station 3 nearest to the experimental plot during the studied period.

\begin{tabular}{lccccc}
\hline & $\mathbf{2 0 0 7}$ & $\mathbf{2 0 0 8}$ & $\mathbf{2 0 0 9}$ & $\mathbf{2 0 1 0}$ & $\mathbf{2 0 1 1}$ \\
\hline Rainfall (mm) & 869 & 796 & 840 & 566 & 616 \\
ETo (mm) & 1160 & 1124 & 1202 & 1132 & 1067 \\
\hline
\end{tabular}

4

5

6

7

8 
2 Table 2. Irrigation treatments applied during the experimental period (2007 to 2011).

\begin{tabular}{lcccc}
\hline Treatment & & \multicolumn{3}{c}{ Irrigation doses applied } \\
\hline & & $2007-2009$ & 2010 & 2011 \\
\hline \multirow{2}{*}{ 1 } & Restriction period $^{[\mathrm{a}]}$ & $40 \% \mathrm{ID}$ & $32 \% \mathrm{ID}$ & $40 \% \mathrm{ID}^{[\mathrm{b}]}$ \\
& Rest of the year $^{\mathrm{T} 2}$ & $110 \% \mathrm{ID}$ & $100 \% \mathrm{ID}$ & $100 \% \mathrm{ID}^{[\mathrm{b}]}$ \\
\hline control & Restriction period & $60 \% \mathrm{ID}$ & $48 \% \mathrm{ID}$ & $50-60 \mathrm{~mm}^{[\mathrm{c}]}$ \\
& Rest of the year & $110 \% \mathrm{ID}$ & $100 \% \mathrm{ID}$ & $70-80 \mathrm{~mm}^{[\mathrm{c}]}$ \\
\hline
\end{tabular}

3 ID means theoretical full irrigation dose

$4{ }^{[a]}$ Restriction period: $17 / 07-02 / 09$ in 2007 and 2008; 13/07-13/09 in 2009; 12/07-30/08 in 2010, 12/07$528 / 08$ in 2011.

$6{ }^{[b]}$ Theoretical irrigation dose adjusted according to the soil water content measured with the FDR 7 probe between $0-60 \mathrm{~mm}$ of the soil depth. The soil water content was kept above $50 \mathrm{~mm}$ in the 8 restriction period and above $80 \mathrm{~mm}$ during the rest of the year.

$9{ }^{[\mathrm{c}]}$ Water content $(\mathrm{mm})$ between $0-60 \mathrm{~cm}$ of the soil depth recorded by the FDR probe. 
1

2 Table 3. Amount of water applied in each irrigation treatment, yield and its components, and 3 water use efficiency (WUE).

\begin{tabular}{|c|c|c|c|c|c|c|c|c|}
\hline Year & Treatment & $\begin{array}{c}\text { Irrigation } \\
\quad(\mathbf{m m})\end{array}$ & $\begin{array}{c}\text { Water } \\
\text { savings } \\
(\%)\end{array}$ & $\begin{array}{c}\text { Yield } \\
\text { (kg/tree) }\end{array}$ & $\begin{array}{l}\text { Relative } \\
\text { yield }(\%)\end{array}$ & $\begin{array}{c}\mathbf{n}^{\mathbf{o}} \text { fruits/tree } \\
(-)\end{array}$ & $\begin{array}{c}\text { Average } \\
\text { fruit weight } \\
\text { (g) }\end{array}$ & $\begin{array}{r}\text { WUE } \\
\left(\mathrm{kg} / \mathrm{m}^{3}\right)\end{array}$ \\
\hline & $\mathrm{T} 1$ & 396 & 23 & 79.2 & 112.4 & 281 & 292.1 & $2.50 *$ \\
\hline \multirow[t]{3}{*}{2007} & $\mathrm{~T} 2$ & 431 & 16 & 84.1 & 119.4 & $309 *$ & 282.3 & $2.59 *$ \\
\hline & control & 516 & -- & 70.5 & 100 & 242 & 296.0 & 2.04 \\
\hline & $\mathrm{T} 1$ & 410 & 20 & 140.4 & 104.5 & 637 & 220.5 & 4.70 \\
\hline \multirow[t]{3}{*}{2008} & $\mathrm{~T} 2$ & 429 & 16 & 146.8 & 109.3 & 680 & 217.9 & 4.80 \\
\hline & control & 515 & -- & $134.4^{[\mathrm{a}]}$ & 100 & 593 & 231.6 & 4.11 \\
\hline & $\mathrm{T} 1$ & 371 & 27 & 72.7* & 168.1 & 306* & 241.6 & $2.22 *$ \\
\hline \multirow[t]{3}{*}{2009} & $\mathrm{~T} 2$ & 449 & 12 & $64.0 *$ & 148.0 & $291 *$ & $224.6^{[b]}$ & $1.84 *$ \\
\hline & control & 512 & -- & $43.3^{[\mathrm{a}]}$ & 100 & 185 & 235.8 & 1.19 \\
\hline & $\mathrm{T} 1$ & 265 & 27 & 76.0 & 104.8 & 352* & 214.7* & 3.69 \\
\hline \multirow[t]{3}{*}{2010} & $\mathrm{~T} 2$ & 285 & 21 & 88.6 & 121.0 & $420 *$ & 217.2 & $4.16^{*}$ \\
\hline & control & 362 & - & 73.2 & 100 & 311 & 237.6 & 3.15 \\
\hline & $\mathrm{T} 1$ & 248 & 21 & $108.7^{*}$ & 143.4 & 433* & 256.1* & $5.03 *$ \\
\hline \multirow[t]{2}{*}{2011} & $\mathrm{~T} 2$ & 253 & 20 & $102.9 *$ & 135.7 & $407 *$ & 253.6* & $4.73^{*}$ \\
\hline & control & 315 & - & 75.8 & 100 & 282 & 271.3 & 3.25 \\
\hline
\end{tabular}

* significant differences with respect to control treatment of each year $(\mathrm{p}<0.05)$.

${ }^{\text {[a] }}$ significant differences between years $(\mathrm{p}<0.05)$.

${ }^{[b]}$ significant differences respect to treatment $\mathrm{T} 1(\mathrm{p}<0.05)$. 
Table 4. Relation Fresh Weight/Dry Weight (FW/DW), before restriction (BR), at the end of the restriction $(\mathrm{ER})$ and at harvest $(\mathrm{H})$ in each treatment and year.

\begin{tabular}{llccccc}
\hline & Treatment & $\mathbf{2 0 0 7}$ & $\mathbf{2 0 0 8}$ & $\mathbf{2 0 0 9}$ & $\mathbf{2 0 1 0}$ & $\mathbf{2 0 1 1}$ \\
\hline BR & T1 & 3.82 & - & - & 3.98 & 4.49 \\
BR & T2 & 3.83 & - & - & 3.87 & 4.65 \\
BR & control & 3.85 & - & - & 3.89 & 4.53 \\
\hline ER & T1 & $\mathbf{5 . 7 4 *}$ & $\mathbf{5 . 5 1 *}$ & $\mathbf{5 . 6 8}^{*}$ & 4.77 & $\mathbf{5 . 0 9}^{*}$ \\
ER & T2 & $\mathbf{5 . 6 8 *}$ & $\mathbf{5 . 7 9 *}$ & $\mathbf{6 . 0 1}^{*}$ & 4.77 & $\mathbf{5 . 1 9 *}$ \\
ER & control & 6.61 & 6.31 & 6.85 & 4.83 & 5.64 \\
\hline H & T1 & 6.52 & $\mathbf{6 . 1 1 *}$ & 9.08 & $\mathbf{3 . 8 1 *}$ & 5.63 \\
H & T2 & 6.51 & 6.59 & 9.48 & $\mathbf{4 . 1 7 *}$ & 5.81 \\
H & control & 6.50 & 6.98 & 9.81 & 4.68 & 5.90 \\
\hline
\end{tabular}

* significant differences with respect to control treatment of each year $(\mathrm{p}<0.05)$. 
2 Table 5. Fruit quality parameters of 'Navelina' citrus trees per treatment and year.

\begin{tabular}{|c|c|c|c|c|c|c|c|c|}
\hline Year & Treatment & $\begin{array}{c}\text { Peel } \\
\%\end{array}$ & $\begin{array}{c}\text { Vitamin C } \\
\text { (mg/100 g juice) }\end{array}$ & $\begin{array}{l}\text { Juice } \\
(\%)\end{array}$ & $\begin{array}{c}\text { TTS } \\
\left({ }^{\circ} \text { Brix }\right)\end{array}$ & $\begin{array}{c}\text { TA } \\
\text { (\% Acids) }\end{array}$ & $\begin{array}{l}\text { Maturity } \\
\text { index (-) }\end{array}$ & $\begin{array}{c}\text { pH juice } \\
(-)\end{array}$ \\
\hline & $\mathrm{T} 1$ & 26.89 & 65.05 & 50.46 & 10.57 & 1.08 & 9.84 & 3.33 \\
\hline \multirow[t]{3}{*}{2007} & $\mathrm{~T} 2$ & 27.08 & 68.68 & 51.66 & 10.67 & 1.05 & 10.37 & 3.36 \\
\hline & control & 26.44 & 70.31 & 50.86 & 10.63 & 0.89 & 12.08 & 3.46 \\
\hline & $\mathrm{T} 1$ & 26.59 & 68.25 & 46.57 & 9.50 & 1.15 & 8.29 & 3.12 \\
\hline \multirow[t]{3}{*}{2008} & $\mathrm{~T} 2$ & 26.36 & 63.34 & 43.80 & 9.87 & 1.01 & 10.09 & 3.14 \\
\hline & control & 26.22 & 67.61 & 46.28 & 9.10 & 0.92 & 10.10 & 3.10 \\
\hline & $\mathrm{T} 1$ & 29.47 & 74.57 & 48.53 & 10.73 & 0.74 & 14.51 & 3.41 \\
\hline \multirow[t]{3}{*}{2009} & $\mathrm{~T} 2$ & 31.63 & 67.97 & 54.10 & 10.80 & 0.68 & 15.84 & 3.29 \\
\hline & control & 26.90 & 67.27 & 51.23 & 11.00 & 0.74 & 15.27 & 3.15 \\
\hline & $\mathrm{T} 1$ & 28.73 & 90.47 & 35.87* & 13.13 & 1.15 & 11.41 & 3.43 \\
\hline \multirow[t]{3}{*}{2010} & $\mathrm{~T} 2$ & 27.13 & 94.22 & 38.57 & 13.73 & 1.21 & 11.44 & 3.41 \\
\hline & control & 29.07 & 95.62 & 41.47 & 13.53 & 1.04 & 12.99 & 3.51 \\
\hline & T1 & 31.53 & 77.34 & 43.57 & 11.73 & 1.04 & 11.52 & 3.51 \\
\hline \multirow[t]{2}{*}{2011} & $\mathrm{~T} 2$ & 30.83 & 77.14 & 42.33 & 11.07 & 0.91 & 12.25 & 3.65 \\
\hline & control & 28.53 & 77.70 & 45.13 & 11.03 & 0.95 & 11.67 & 3.60 \\
\hline
\end{tabular}

3 *significant differences with respect to control treatment of each year $(\mathrm{p}<0.05)$.

4 TSS: Total Soluble Solids content

5 TA: Titratable Acidity 